\title{
Exploration for Late Cretaceous turbidites in the Equatorial African and northeast South American margins
}

\author{
J. Kelly ${ }^{1, *}$ \& H. Doust ${ }^{2}$
}

1 Tullow 0il plc, 1 Central Park, Leopardstown, Dublin 18, Ireland

2 VU Amsterdam and Universiteit Utrecht, Mauvestraat 4, 2596 XR Den Haag, The Netherlands

* Corresponding author: E-mail: Jerome.kelly@tullowoil.com

Manuscript received: 13 July 2016, accepted: 8 August 2016

\section{Abstract}

The Suriname-Guyana and Ghana-Ivorian Basins exhibit strong geological similarities which are of interest from a petroleum exploration point of view. These include (1) a well-developed system of Late Cretaceous erosional canyons allowing coarse-grained shallow-water clastics to enter the deep marine basin to form attractive turbidite exploration targets; (2) a broad shelf with strong longshore currents which sort and transport coarse clastics into the canyon heads; (3) an organic-rich Cenomanian-Turonian hydrocarbon source rock which is thermally mature in the centre of the basin; and (4) a series of extensional fault-networks along the shelf margin that extend upwards from the Rift Sequence into the overlying Drift Sequence and which, along with the canyon geometries, enable migrating oil and gas to accumulate in combination structural and stratigraphic traps. In June 2007, Tullow and its partners made an important discovery in offshore Ghana, at Mahogany, which subsequently became the giant Jubilee field. Tullow is currently applying the same geoscientific technologies in offshore Suriname in the search for analogous subtle combination traps.

Keywords: exploration, offshore, oil fields, Suriname, West Africa

\section{Introduction}

The Suriname-Guyana and Ghana-Ivorian Basins are situated on opposite sides of the Central Atlantic and, although plate reconstructions of the Albian-Aptian show that they are not strictly conjugate, i.e. they did not lie immediately opposite one another before ocean opening, they exhibit striking geological similarities that are relevant from a petroleum exploration point of view. These include:

1. a well-developed system of Late Cretaceous erosional canyons that provided the means by which coarsegrained shallow-water clastics could enter the deep marine basin to form very attractive turbidite exploration targets,

2. a broad shelf with strong longshore currents which - now and in the geological past - have sorted and transported coarse clastics into the canyon heads,
3. an organic-rich Cenomanian-Turonian hydrocarbon source rock which is thermally mature in the centre of the basin, and

4. a series of extensional fault-networks along the shelf margin that extend upwards from the Rift Sequence into the overlying Drift Sequence and which, along with the canyon geometries, provide the conditions for migrating oil and gas to accumulate in combination structural and stratigraphic traps.

The evolution of the oil industry's search for commercial hydrocarbons is strikingly similar in both basins. Prior to 2007, Ghana had only one small producing oil field, but a number of exploration wells drilled there contained indications of petroleum, demonstrating that the basin had the potential to deliver more commercial discoveries. Today, the Suriname Basin is in a very similar situation: oil is commercially produced from the onshore Tambaredjo Field and, although no commercial oil discoveries have yet been made offshore, many wells there have 
located good oil shows, indicating the basin's potential to be a future oil-producing region.

In June 2007, Tullow and its partners unlocked the potential of the Ghana-Ivorian Basin, when they made an important discovery at Mahogany, which subsequently became the giant Jubilee field. Today more than 100,000 barrels of oil per day are produced from the area. Tullow is currently applying the same geoscientific technologies and expertise in offshore Suriname in the search for analogous subtle combination traps in blocks 47, 54 and 31. Hopefully the success of Jubilee, which has turned Ghana into a major oil-producing nation, can be repeated in Suriname during the next few years.

\section{Historical background}

Since its inception in 1986, the focus of Tullow's exploration efforts has been in Africa, and particularly on the Atlantic margin of central West Africa. However, in the middle of the last decade, the company recognised that, based on plate tectonic principles, parts of the sequence on the conjugate western margin of the Atlantic (Darros de Matos, 1999; Yang \& Escalona, 2011; Bryant et al., 2012) may have similar geology. In the equatorial regions, this conjugate relationship has particular relevance in the Late Cretaceous period, when the Central Atlantic 0cean basin was just beginning to drift apart (Yang \& Escalona, 2011; Dailly et al., 2013; Henderson, 2014).

The concept was based on experience gained through operations in Côte d'Ivoire, which Tullow entered in 1997, joining Ranger and Canadian Natural Resources (CNR) in redevelopment of the suspended Espoir Field (Fig. 1). A solid understanding of the stratigraphy and geological evolution of the western edge of this part of Africa was soon developed (Dailly et al., 2013) and, following a number of other oil discoveries in this area, it was recognised that the Equatorial Atlantic continental margin had the potential to develop into a major petroleum province. The discovery of the Baobab Field in 2001, with potential recoverable reserves of 250 million barrels of oil, underlined this potential. In spite of this, the industry in general seemed slow to act, and the region remained relatively under-explored compared to neighbouring areas such as Nigeria and Cameroon. This gave Tullow and other like-minded companies the opportunity to build a portfolio of licences in offshore Côte d'Ivoire, and then, recognising that geological trends do not stop at borders, to expand that position into the western part of Ghana (Fig. 1).

\section{Petroleum system elements in the Abidjan-Tano Basin}

One of the key 'ingredients for success' identified was the growing evidence that a rich and widespread, oil-prone source rock was present in the Late Cretaceous sequence, as demonstrated by the numerous oil discoveries and also by the abundance of oil seepages along the shoreline in both Côte d'Ivoire and Ghana (Fig. 2; Lamorde, 2012).

The South and Central Atlantic continental margin basins developed during the Early Cretaceous in response to northwardpropagating rifting. In the equatorial zone of the Gulf of Guinea, the basins were formed as a result of extension along westeast-trending transform fracture zones (Nemčok et al., 2015). A period of non-marine syn-rift deposition was followed by rapid post-rift subsidence in the mid-Cretaceous and the creation of relatively isolated and narrow sub-basins with deep marine sediments (Wells et al., 2012). The oil source rock that forms the basis of the main petroleum system here corresponds to the Late Cretaceous Cenomanian to Turonian phase of global anoxia (OAE 2), when northwest Africa lay on the eastern flank of the North Atlantic. Upwelling nutrient-rich waters resulted in high organic productivity and the accumulation of organicrich sediments (Trabucho Alexandre, 2011). Deep-sea drilling wells from the area encountered mainly Type II organic material with TOCs (total organic carbon) of up to $10 \%$ (Brownfield \& Charpentier, 2006). Older source rocks belonging to syn-rift to transitional cycles below the post-rift contain mixed oil and gas-prone source rocks of marginal marine origin that are also likely to have contributed some of the petroleum charge to the Espoir and Baobab fields.

With this oil source rock concept as a foundation, geological models were developed to create a series of hydrocarbon play concepts (Fig. 3). These play concepts best represent how oil and gas may be distributed - and trapped at different stratigraphic levels and in different locations across the basin. By gathering technical data, such as seismic and electromagnetic surveys and shallow cores, geologists can translate these general concepts into specific oil and gas prospects.

\section{Crossing the Atlantic}

The Baobab discovery led some geologists to recognise the potential of the Equatorial margins of the Central Atlantic which was by this stage bracketed by large oil accumulations: Baobab and Dome Flore in West Africa, Tambaredjo in Suriname, and fields in the Potiguar Basin in South America, (Benkhelil et al., 1998; Fig. 4), suggesting that success on the African side could be replicated on the South American margin. Although several seismic surveys had been carried out on the western side of the Central Atlantic and quite a lot of wells had been drilled along the coasts and in shallow waters, there were virtually no exploration wells on the upper continental slope (in water depths greater than $200 \mathrm{~m}$ ); it was on the upper slope of the eastern, African, margin of the ocean that Baobab lay. Most of the wells on the South American side, in Brazil, Suriname and Guyana, were drilled in the 1970s and 1980s when oilfield technology limited how far out to sea wells could be drilled. Developments in drilling techniques and rig capabilities in the last years of the 


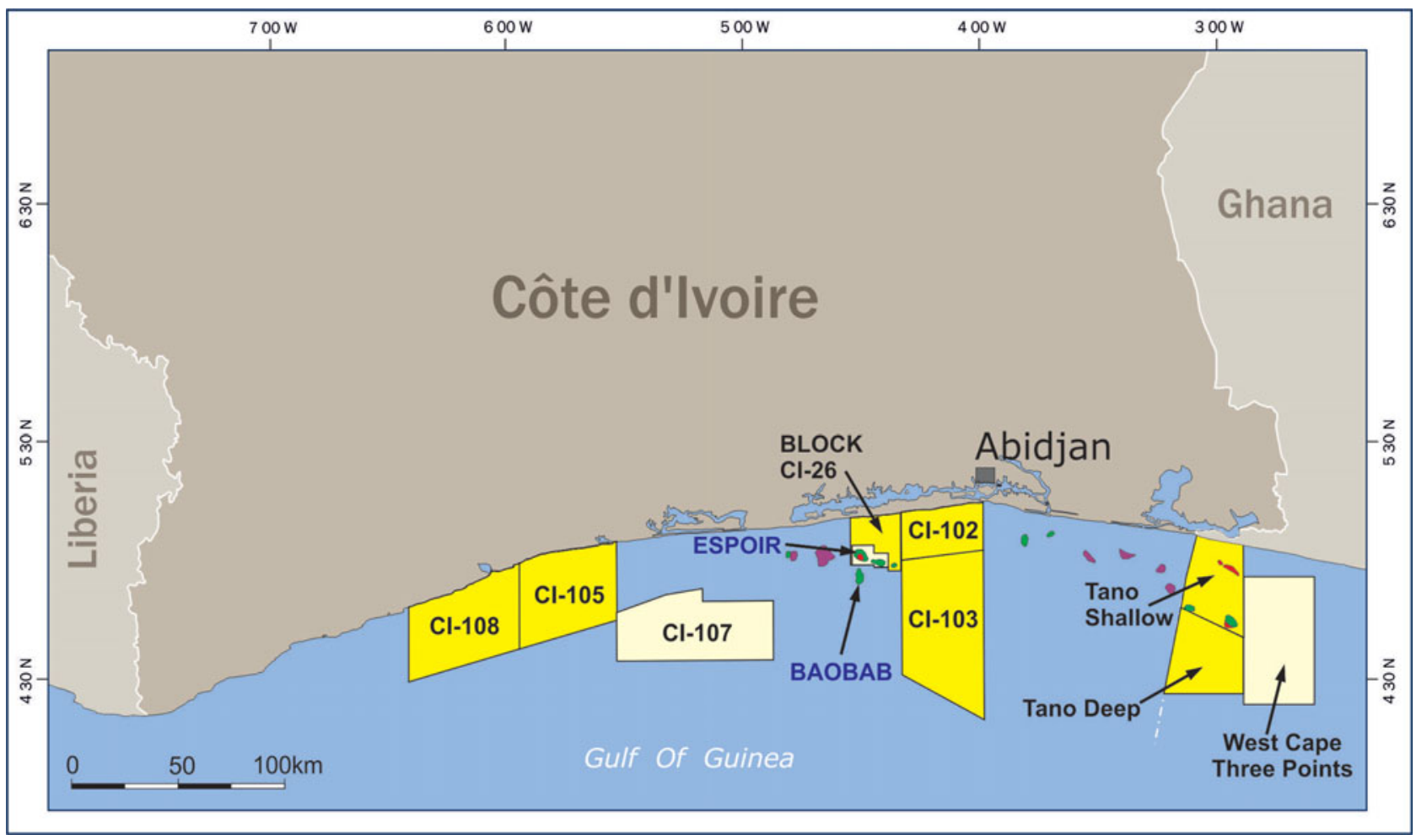

Fig. 1. Licence position of Tullow Oil plc in Côte d'Ivoire and Ghana by 2006.

20th century were, however, enabling such deep water areas to become accessible to the drill-bit for the first time.

\section{Comparing the Equatorial margins}

The African and South American plates were joined together until about $100 \mathrm{Ma}$ ago. In Equatorial West Africa and the conjugate parts of northern Brazil the opening of the Atlantic Ocean took place in the Middle Cretaceous (Aptian-Albian, 115$105 \mathrm{Ma}$ ) and was preceded by an Early Cretaceous continental rift cycle as noted above. On the Guyana margin, however, the break-up history began earlier and was more complex: rifting began in the mid- to late Jurassic (180-150 Ma) and was followed by a period of carbonate platform development. Subsequent Early Cretaceous rifting in the South Atlantic led to counterclockwise plate rotation causing uplift, compression and erosion in offshore Suriname (Casey \& Norton, 2015), especially affecting the Demerara Plateau (Bihariesingh \& Griffith, 2013). These differences influenced the Late Cretaceous opening or Drift cycle in these respective areas, but in all cases a passive margin was formed and further evolution was expected to be essentially comparable, at least as far as petroleum prospectivity is concerned (Wong, 2014).

The results of exploration for oil and gas elsewhere in the South Atlantic had demonstrated that the post-rift passive margins of West Africa and Brazil were characterised by comparable petroleum systems (Beglinger et al., 2012a,b) and this sug- gested the possibility that similar relationships may hold true in the equatorial segment. If this was the case, the same hydrocarbon plays and prospects that had been identified in offshore Ghana and Côte d'Ivoire might exist in northern Brazil, French Guiana, Guyana and Suriname.

Initial research on the geological evolution of both margins demonstrated that there were indeed strong similarities in their stratigraphic and structural framework during the Early Drift Phase. The latter began around $100 \mathrm{Ma}$ ago in the Albian Period and continued for over $30 \mathrm{Ma}$ until the end of the Cretaceous (Fig. 5). Therefore there was good evidence that the same key elements for exploration success existed on South American side of the Equatorial Atlantic, specifically:

1. Rich and prolific hydrocarbon source rocks as in West Africa.

2. The presence of large submarine canyons that deliver coarsegrained (sandy) sediments from the near-shore to the deeper waters by means of channelised, high-density turbidity flows into areas where no exploration for oil and gas had yet occurred.

3. A basin architecture that lends itself to the development of trap geometries, in particular in the form of drape above the faulted palaeotopography that remained at the beginning of the Drift Phase. Reactivation of these inherited rift structures assists in the formation of combination structural and stratigraphic (sand pinch-out) traps.

Evidence for the presence of oil-generating Late Cretaceous source shales has already been alluded to. 


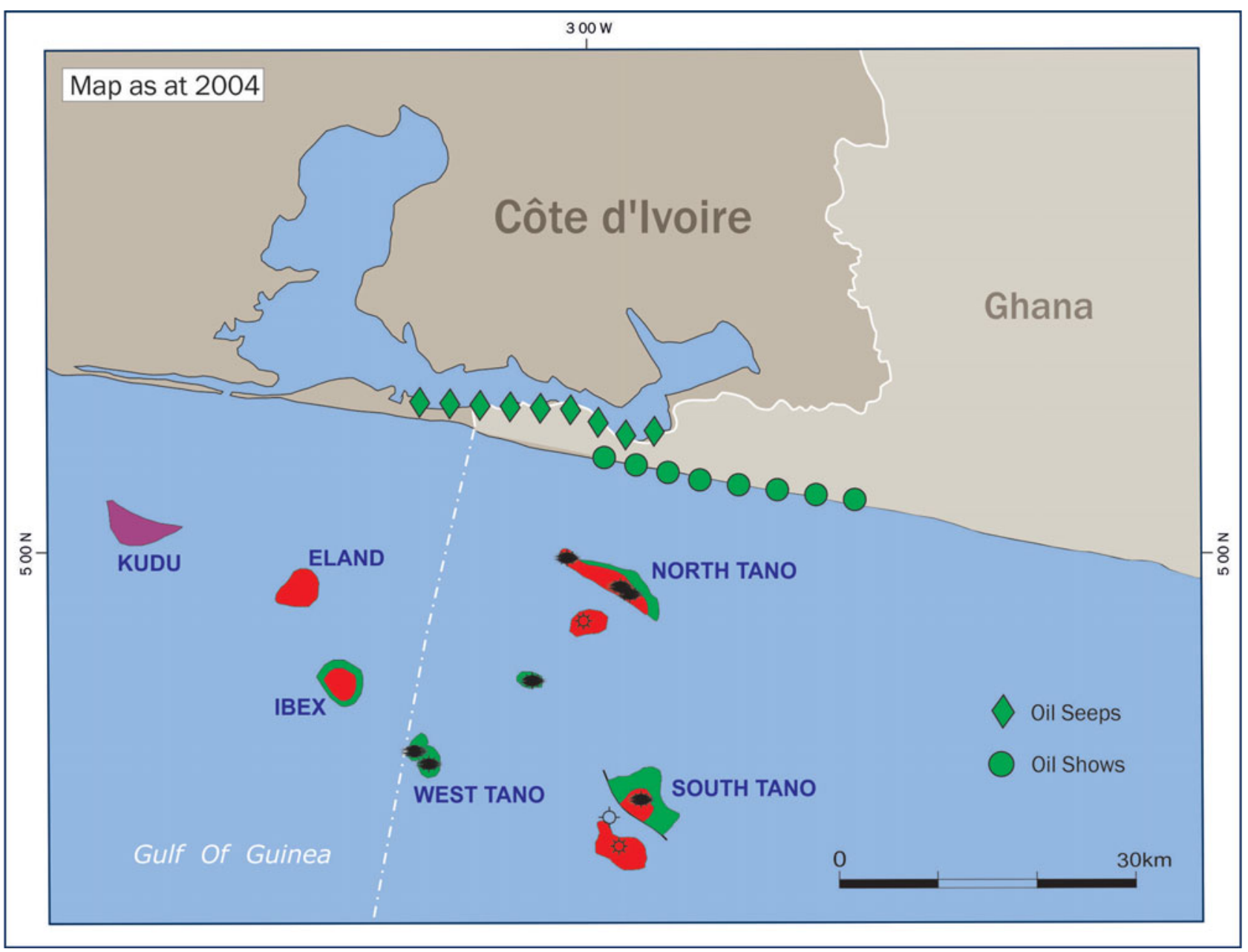

Fig. 2. Oil/gas discoveries and seeps in the Tano Basin.

This has been supported by numerous studies that suggested that the rich, organic shales of the Turonian and Cenomanian periods, to which the oil discoveries and seeps in West Africa were strongly linked, were also developed along the Atlantic margin of South America (Fig. 6; Schiefelbein et al., 2000; Beglinger et al., 2012b). This was not new information to geologists in Brazil and Suriname, who knew that their respective oil fields could be linked to source rocks of this age, but it did give further energy to the view that there was the potential for many more such discoveries. On the Demerara Plateau of Suriname, The Cenomanian-Turonian sequence is over $500 \mathrm{~m}$ thick and contains horizons with up to 7\% TOC Type II marine source material (Griffith, 2015). 0cean Drilling (ODP) wells in the area have logged laminated organic claystones with up to $30 \%$ TOC in the same interval (Mosher at al., 2004).

As to the second element, the acquisition of modern 3D seismic in Ghana and Côte d'Ivoire confirmed the widespread development of submarine canyons as conduits to transport sands into deeper waters, where they form excellent reservoirs for oil and gas. The same surveys were undertaken in Suriname a few years later, and confirmed that similar features link the sandy shelf-areas to the adjacent continental slope (Fig. 7A, B). On both margins, meandering channels were identified on seismic data, and the amplitudes of the reflections strongly supported the belief that these could be filled with turbidite deposits, predominantly made up of good reservoir sands.

Finding thermally mature oil-generating shales and turbidite sand reservoirs does not, of course, guarantee the discovery of large oil fields. Critical, too, are the paths of migration, which are not only influenced by the development of sands, but also by the presence of barriers (either faults or sand pinch-outs). Where such barriers are limited or non-existent, oil and gas may continue migrating to the edge of the basin to be trapped in shallow reservoirs, as in the case of the Tambaredjo Field (Dronkert \& Wong, 1993), or simply leak away in surface seeps (common on both sides of the Equatorial Atlantic). Evidence for structural depressions in the Late Cretaceous sequence bounded by extensively faulted and folded pre-Albian high blocks provides scope for the accumulation of ponded slope and channel turbidites (Casey \& Norton 2015; Griffith, 2015). The same structure is likely to inhibit lateral migration away from parts of the Demerara Plateau. 


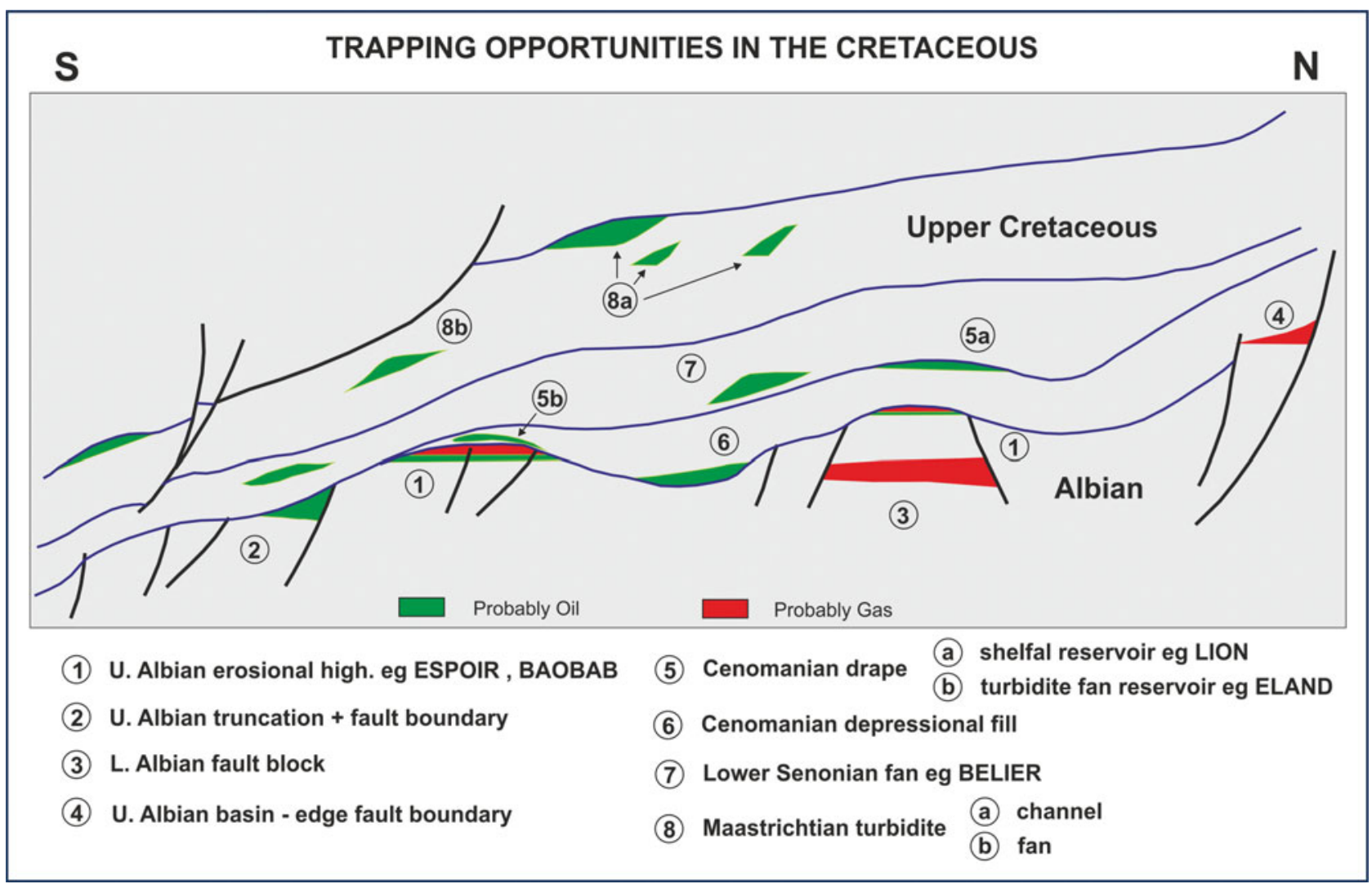

Fig. 3. Sketch showing potential trapping geometries in the Cretaceous of Equatorial Africa. Highly mature source rocks in the syn-rift sequence are probably the origin of gas and some oil in the Albian faulted structures. Channel and fan plays in the later Cretaceous post-rift sequence belong to a different petroleum system, Cenomanian-Turonian marine Type II source rocks.

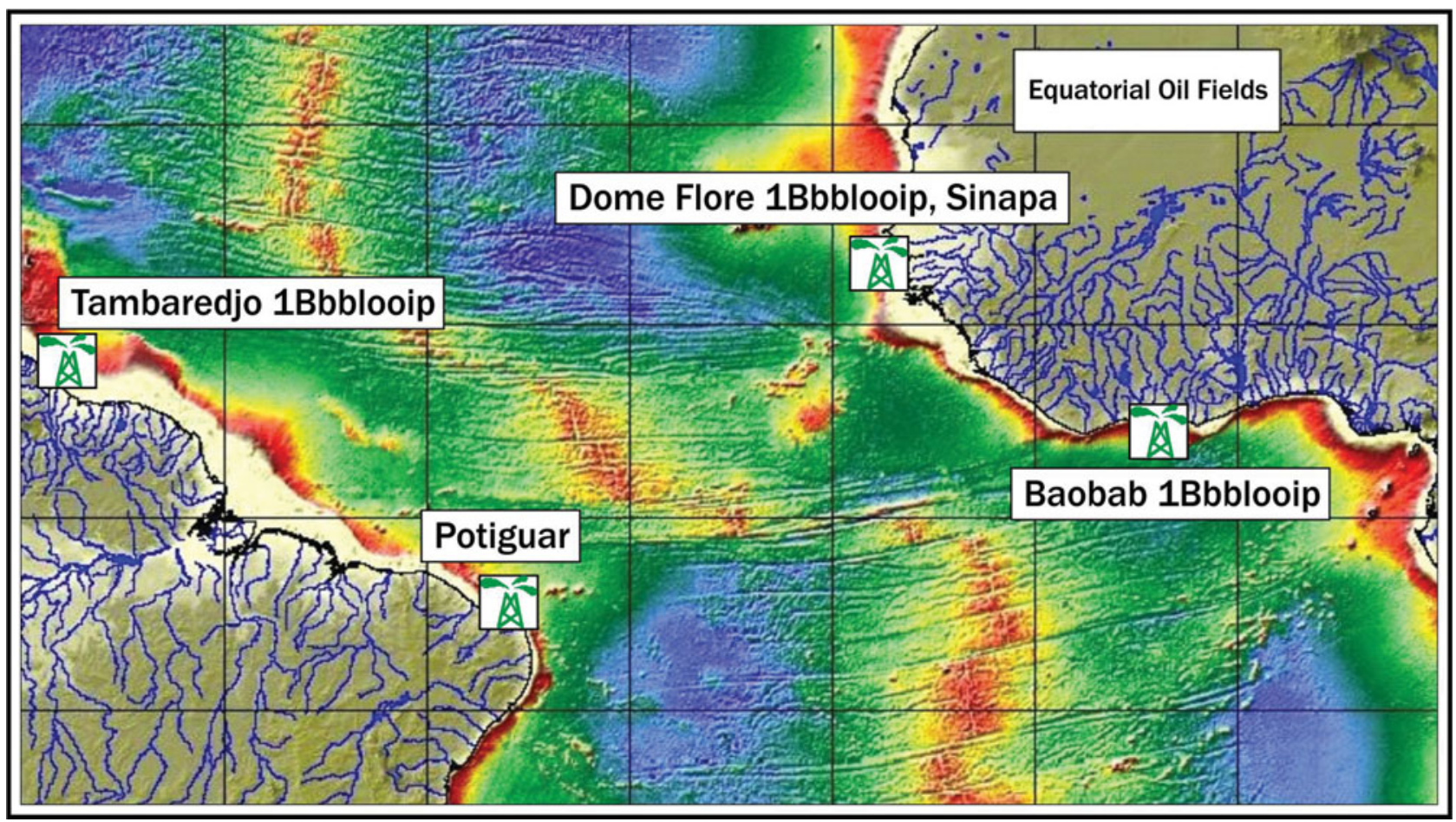

Fig. 4. Large oil accumulations around the edges of the Equatorial Atlantic (Bbooip - billions of barrels of oil originally in place). 


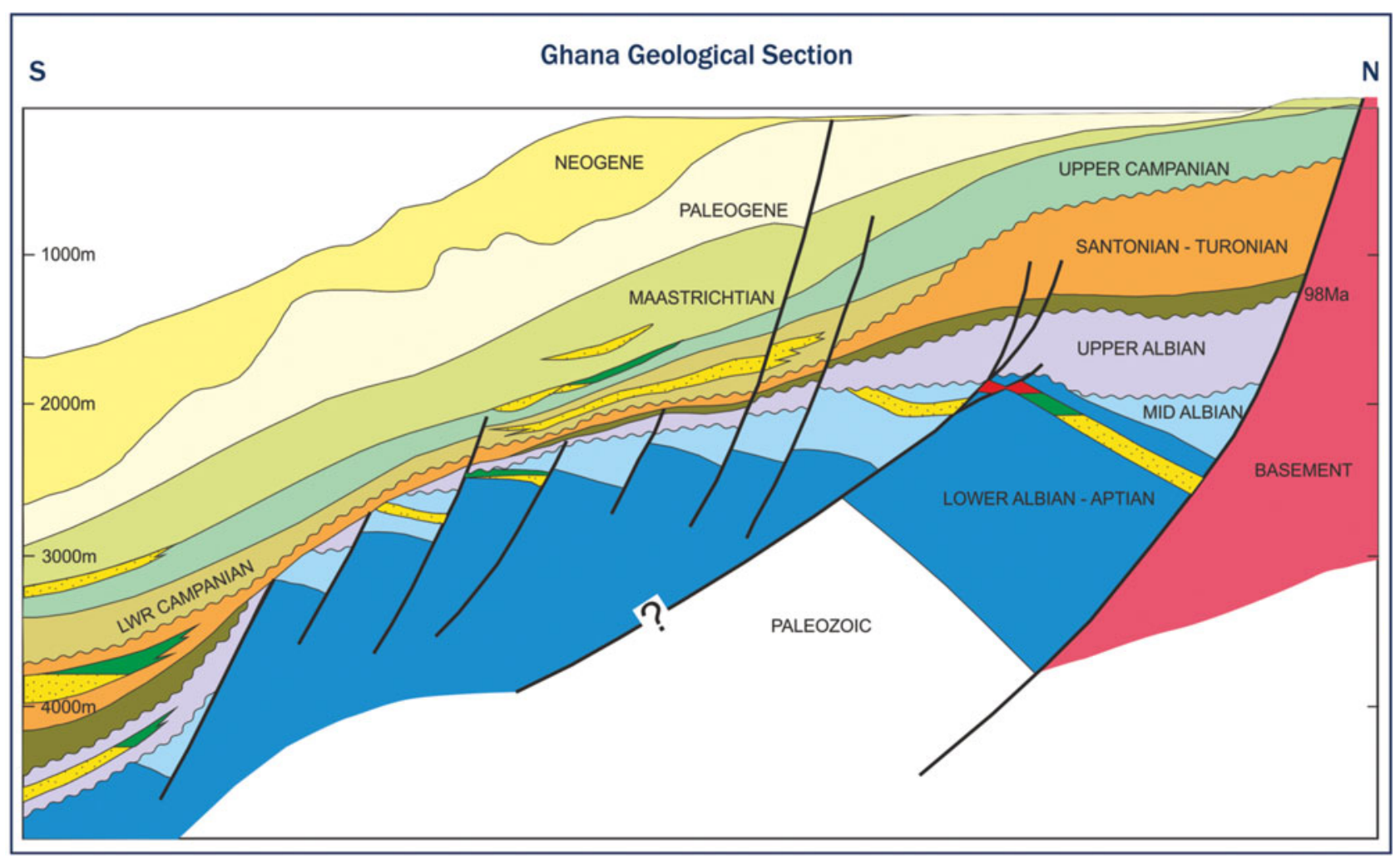

(a)

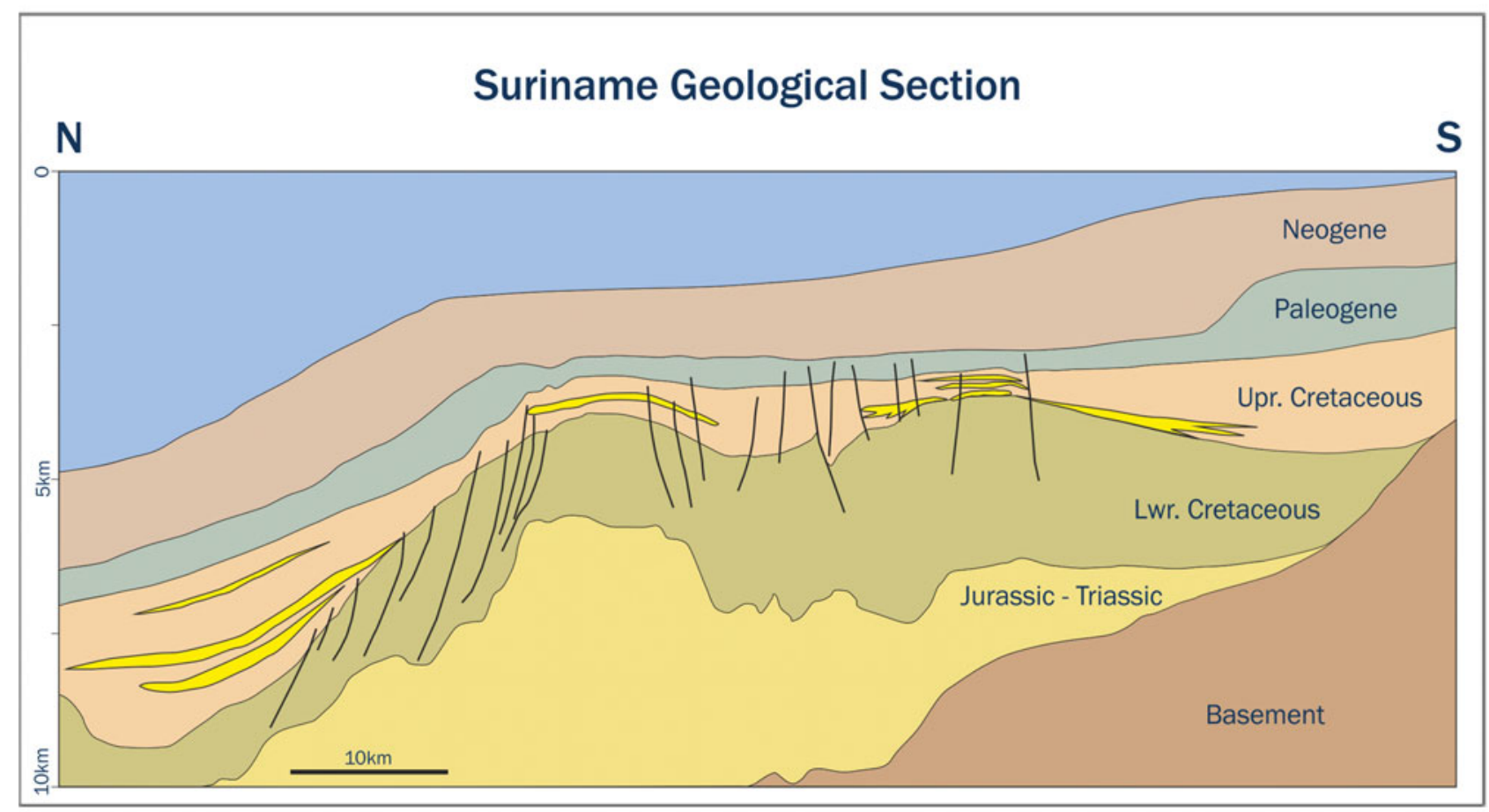

(b)

Fig. 5. Stratigraphic and structural architecture on the (A) African and (B) South American side of the Equatorial Atlantic. 


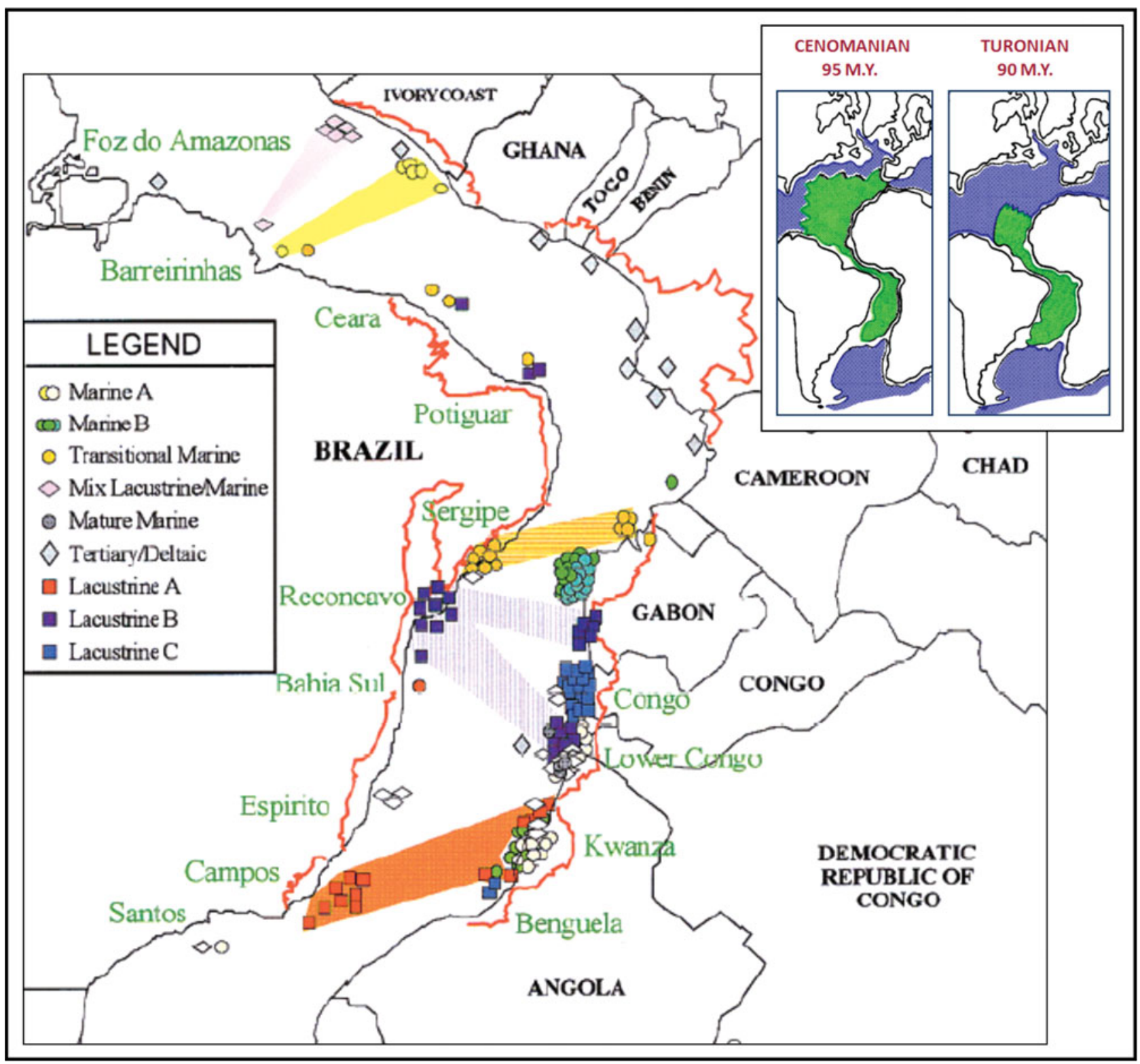

Fig. 6. Oil families and their correlation across the Atlantic (from Schiefelbein et al., 2000).

\section{Delivering the Tano Basin play}

Promising structural and stratigraphic trap geometries could be seen in the basins of both Ghana and Suriname (Fig. 8A, B); the question was, would these structures and possible sand pinchouts be sufficient to retain the large volumes of oil required in such deep waters, to make a future oil or gas field development commercially viable where drilling was expensive?

This question was finally answered in June 2007, when the Mahogany-1 exploration well was drilled by a Tullow-KosmosAnadakro Joint Venture in the Tano Basin of western Ghana. The well penetrated a series of stacked, high-porosity turbidite sandstones in the Upper Cretaceous (Santonian-Turonian) section containing a $270 \mathrm{~m}$ gross hydrocarbon column, including $95 \mathrm{~m}$ of oil-bearing sands. The oil was light, sweet crude, and geochemical analysis demonstrated that it originated from
Turonian source rocks, just like the oil in the Tambaredjo Field.

The Mahogany-1 discovery was followed up in August 2007 by the Hyedua- 1 well which confirmed that the field formed a large accumulation straddling two licence areas. The accumulation, now known as the Jubilee Field, was rapidly developed, using the latest technology and involving a very high level of intercompany cooperation The field, in which Tullow holds a $35.48 \%$ interest, came on stream within a record-breaking time of three years from the date of discovery and is currently producing more than 100,000 barrels of oil per day (Fig. 9). Jubilee is estimated to contain $600-800$ million barrels of ultimately recoverable oil.

Success at Jubilee was followed by other discoveries in the basin, several of which are now grouped collectively into the Tweneboa-Enyenra-Ntomme (TEN) complex, currently under 


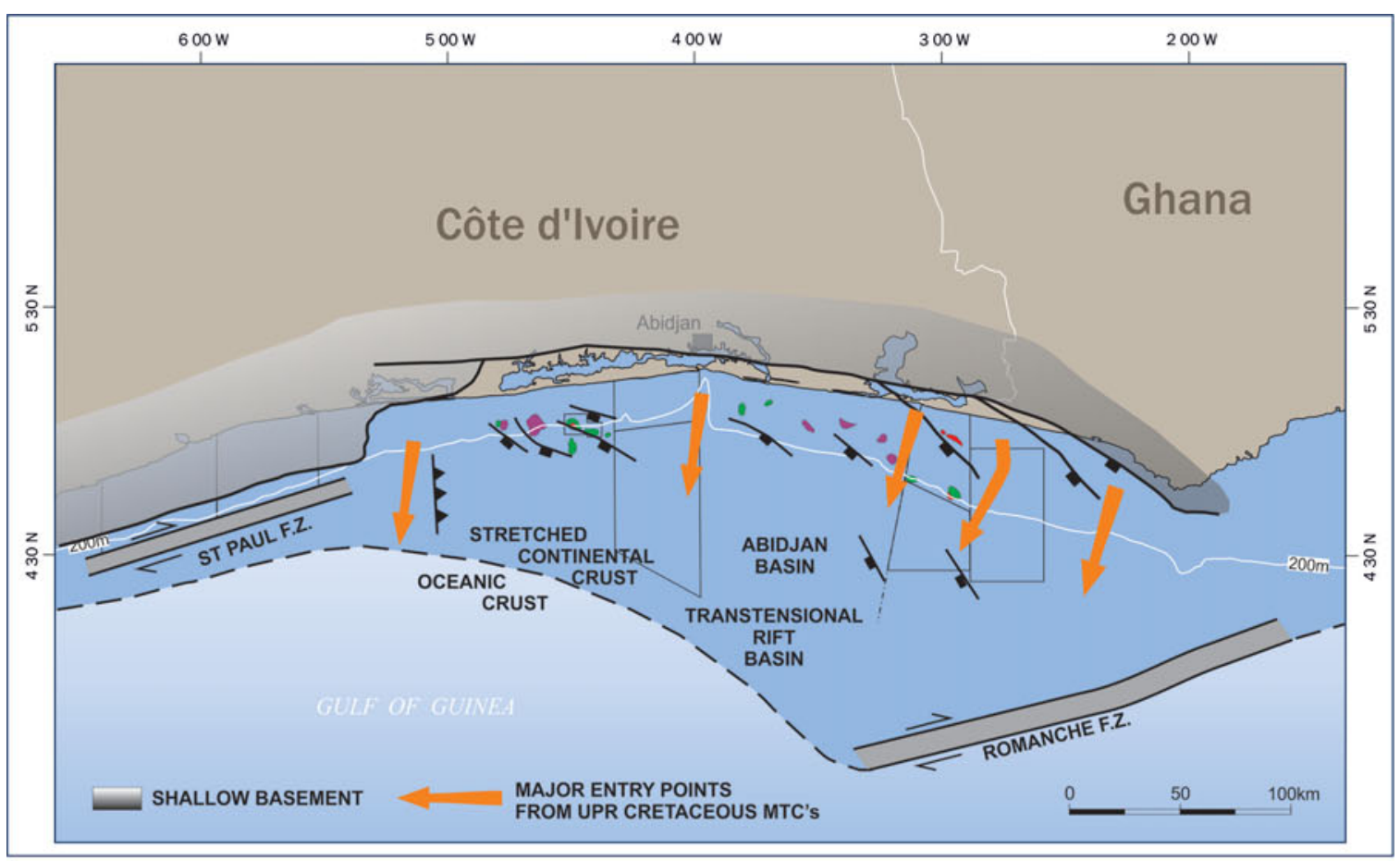

(a)

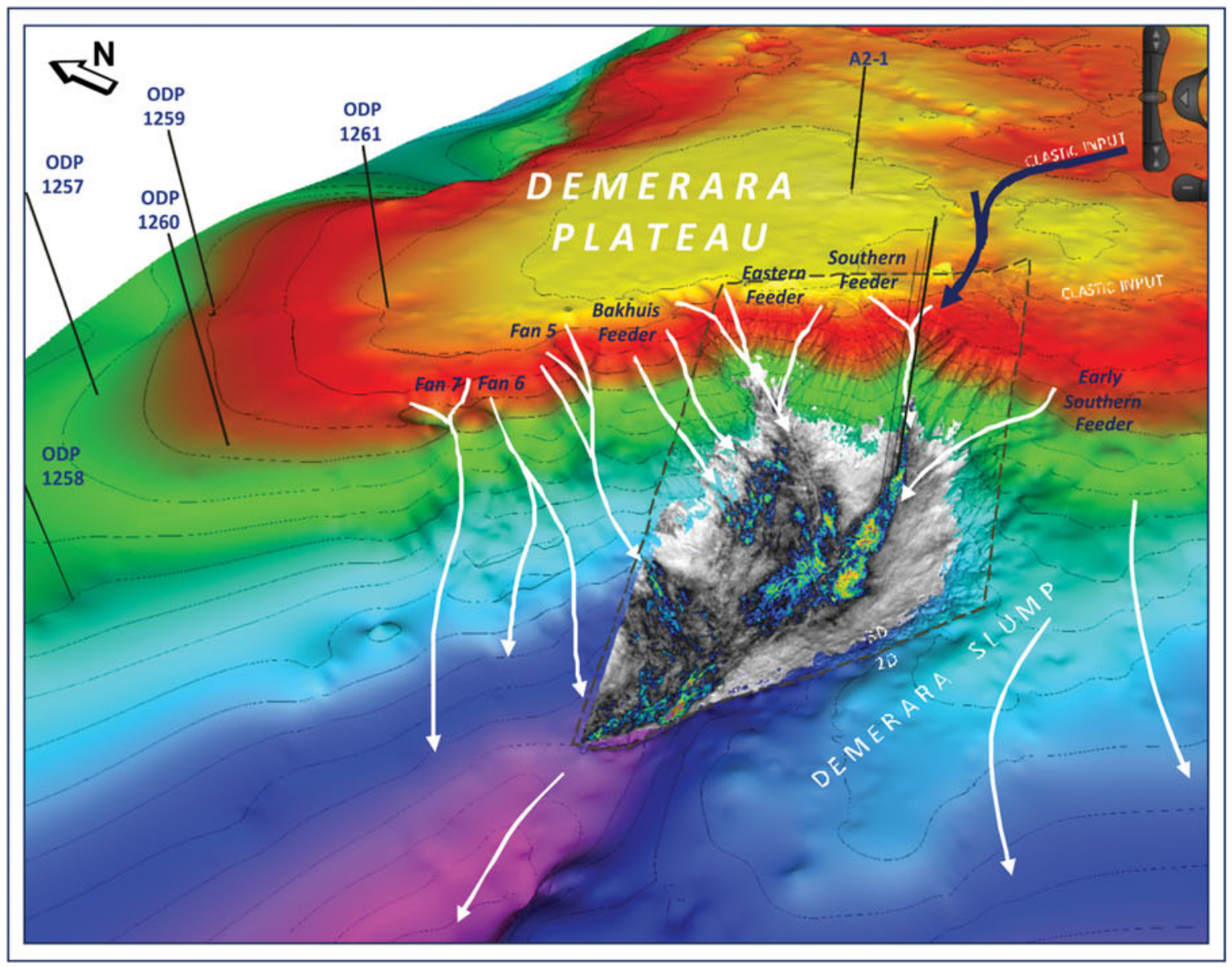

(b)

Fig. 7. Major sediment entry points on the, (A) African and (B) South American side of the Equatorial Atlantic. 


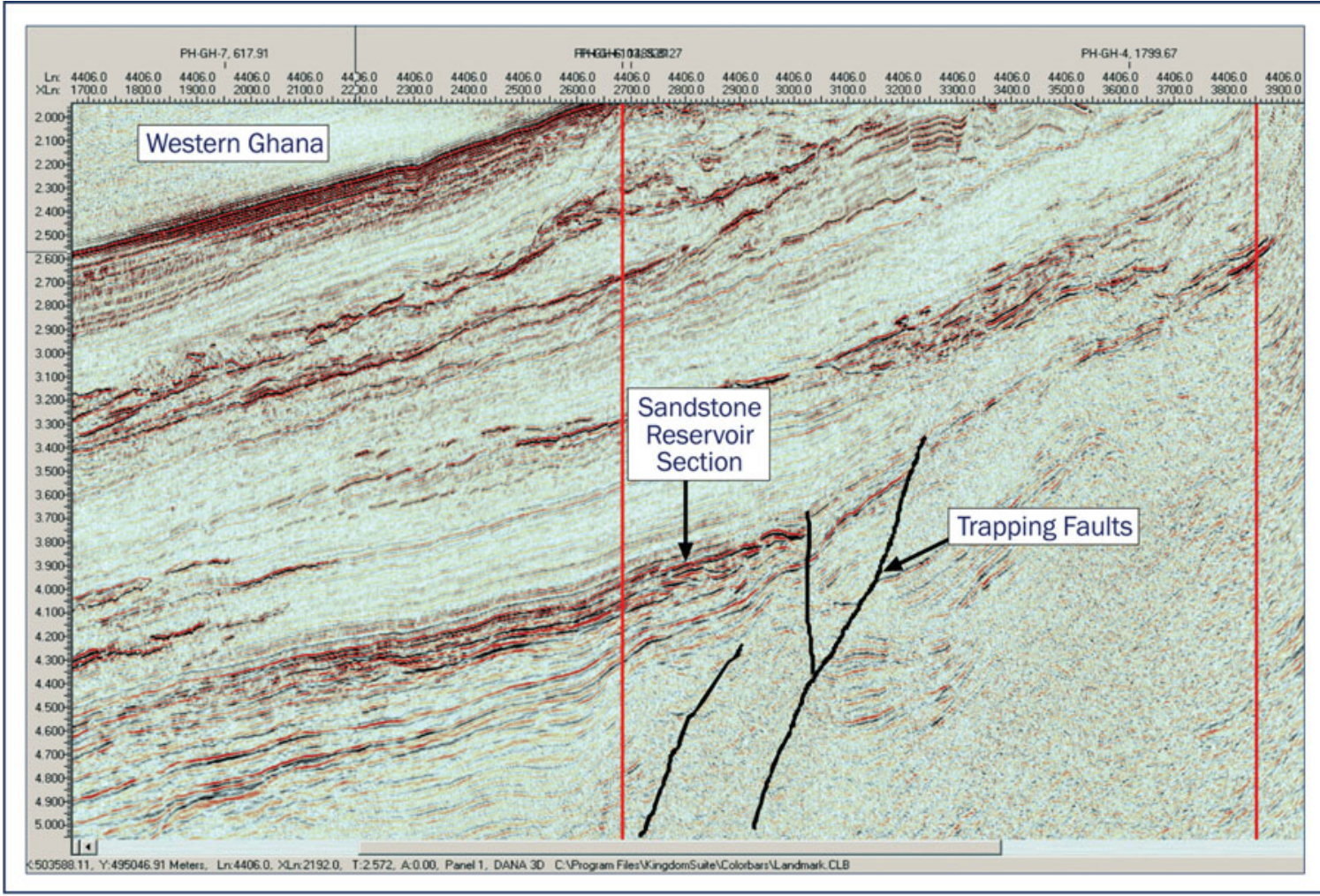

(a)

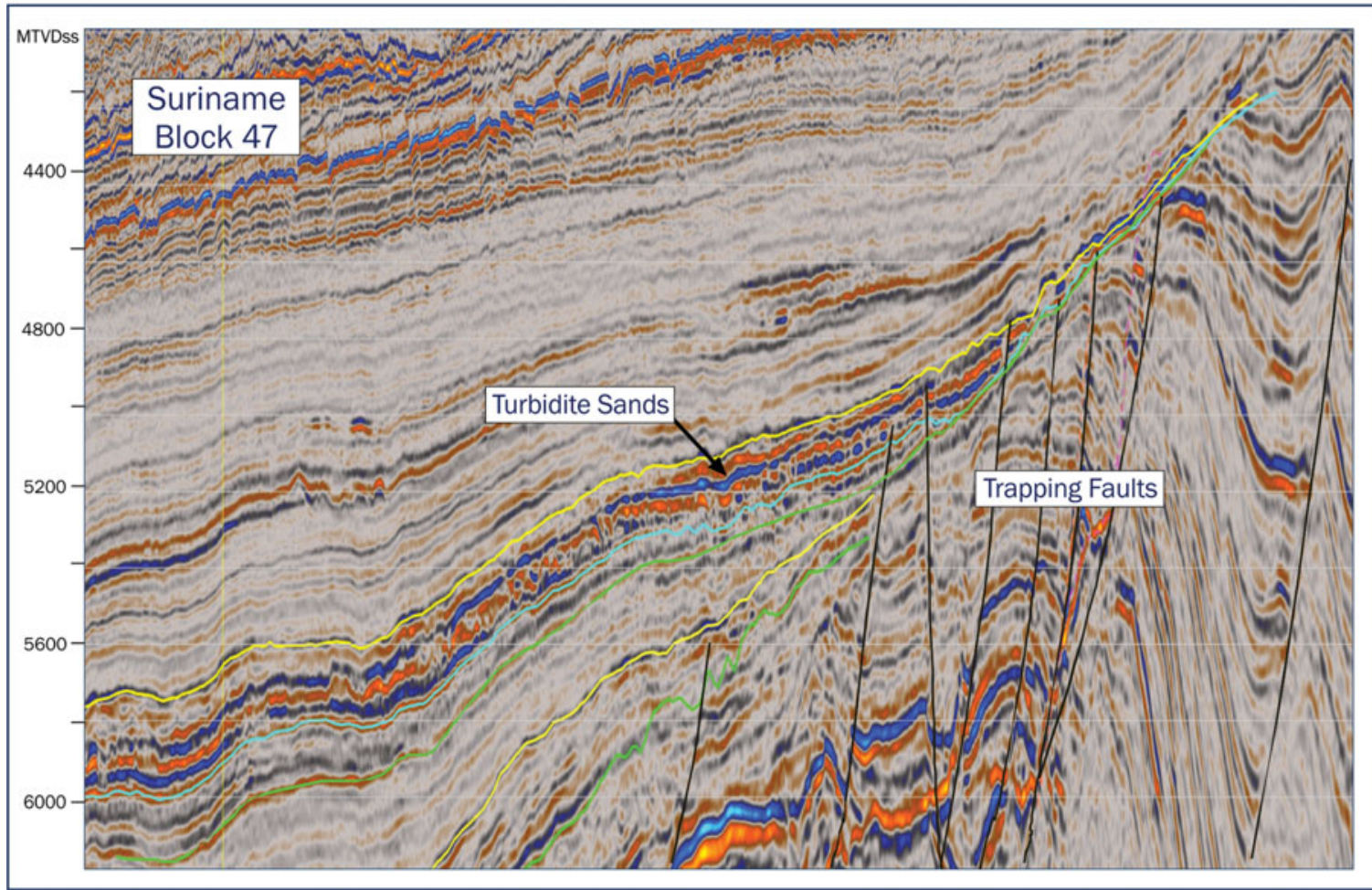

(b)

Fig. 8. Seismic lines showing stratigraphic-structural trapping, (A) in Ghana and (B) in Suriname. 


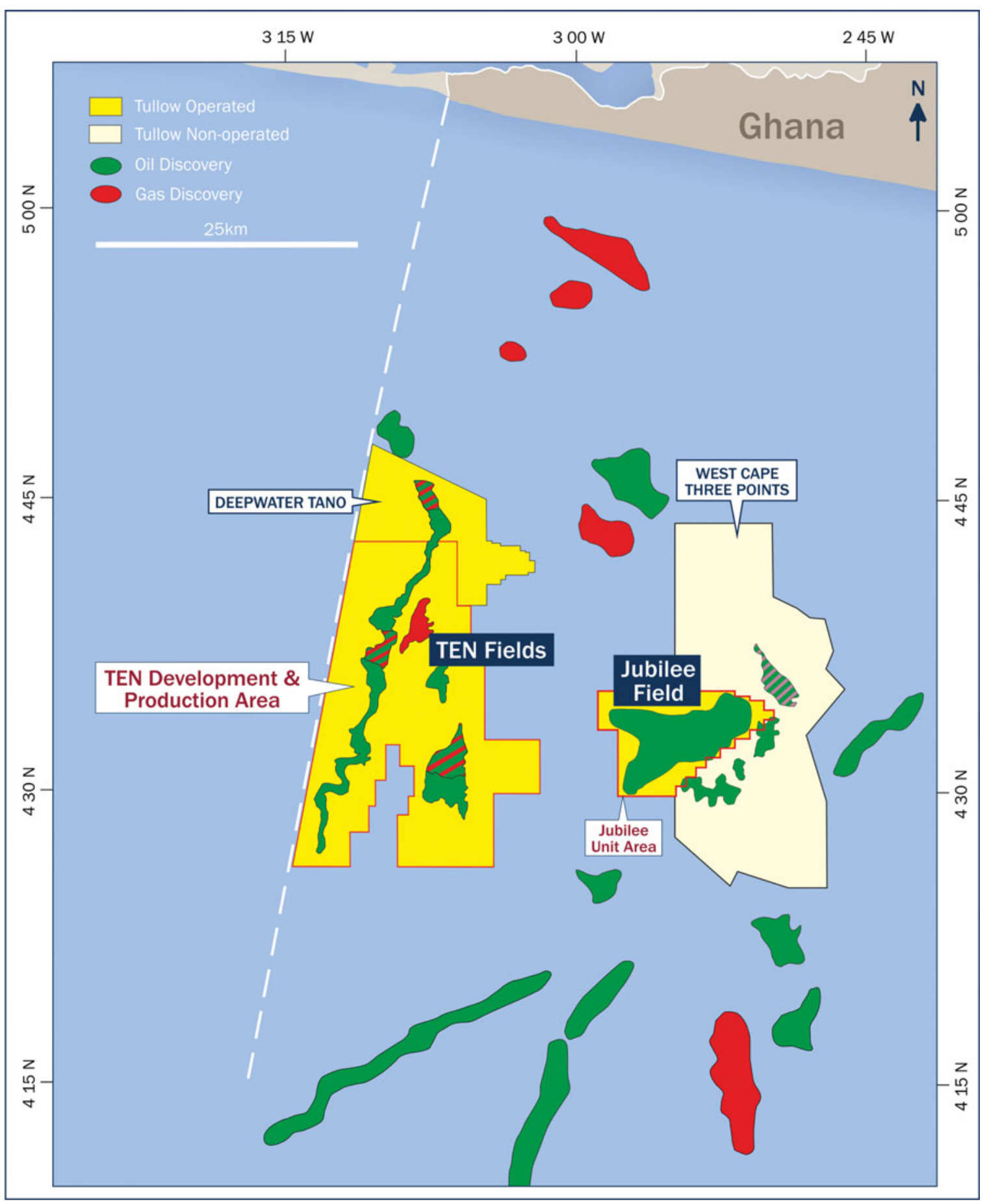

Fig. 9. Recently discovered oil and gas fields, Tano Basin, Ghana.

development. Ongoing efforts continue in Ghana to identify satellite prospects that may add to the volumes of oil already found, and Tullow hopes to bring the complex on stream in late 2016.

\section{The next stage}

Major success has come to Ghana, which is now a leading oil and gas producer. Can that success be repeated in Suriname? Not only is it clear that Suriname shares all the primary geological ingredients needed for the presence of accumulations in Upper Cretaceous turbidite reservoirs, but the evolution of exploration efforts here also bears striking similarities to the long, patient story of the search for oil and gas in Ghana. Prior to 2007, Ghana had only one small, producing oil field, but it also had several exploration wells with oil shows, which provided testament to the potential of the basin to deliver one or more commercial hydrocarbon discoveries. 
Today, the Suriname Basin is in a similar situation; there is production onshore from the Tambaredjo Field, but no commercial oil discoveries in the offshore (Wong, 1989, 1998; Dronkert \& Wong, 1993; Rivera Rabelo, 2006; Goss et al., 2009; Leo et al., 2015; Nemčok et al., 2015). However, many of the offshore wells have encountered good oil shows, indicating that the basin has potential. In June 2007, the potential of the Tano Basin was finally realised with the Mahogany discovery. Today, the same geoscience technologies and expertise are being applied towards the same goal in Suriname. They led to early success with the discovery of $72 \mathrm{~m}$ of net pay in Late Cretaceous turbidite fans in the Zaedyus well in French Guiana. Since then, ExxonMobil has had success in a similar Late Cretaceous turbidite fan play with well Liza-1 in Guyana (90 m oil sand), so clearly the concept of analogous petroleum systems works. Currently, a number of exploratory wells are underway or planned in Suriname; hopefully the success which has turned Ghana into a major oilproducing nation can be repeated in Suriname over the next few years.

\section{References}

Beglinger, S.E., Doust, H. \& Cloetingh, S., 2012a. Relating petroleum system and play development to basin evolution: West African South Atlantic basins. Marine and Petroleum Geology 30: 1-25.

Beglinger, S.E., Doust, H. \& Cloetingh, S., 2012b. Relating petroleum system and play development to basin evolution: Brazilian South Atlantic margin. Petroleum Geoscience 18: 315-336.

Benkhelil, J., Mascle, J. \& Guiraud, M., 1998. Sedimentary and structural characteristics of theCretaceous along the Côte d'Ivoire-Ghana transform margin and in the Benue trough: acomparison. In: Mascle, J., Lohmann, G.P. \& Moullade, M. (eds): Proceedings of the OceanDrilling Program, Scientific Results 159: 93-99.

Bihariesingh, V. \& Griffith, C., 2013. Petroleum: the new economic boost for Suriname. GeoExpro 10(4): 22-26.

Brownfield, M.E. \& Charpentier, R.R., 2006. Geology and total petroleum systems of the Gulf of Guinea province of West Africa. USGS Bulletin 2207-C: 22 pp.

Bryant, I., Herbst, N., Dailly, P., Dribus, J.R., Fainstein, R., Harvey, N., McCoss, A., Montaron, B., Quirk, D. \& Tapinnier, P., 2012. Basin to basin: plate tectonics in exploration. Oilfield Review 24(3): 38-57.

Casey, K. \& Norton, I., 2015. Jurassic and Cretaceous tectonic evolution of the Demerara Plateau - implications for South Atlantic opening. 34th GCSSEPM Research Conference, 13-16 December 2015, Houston, TX, USA: 600-614. Conference proceedings.

Dailly, P., Henderson, T., Hudgens, E., Kanschat, K. \& Lowry, P., 2013. Exploration for Cretaceous stratigraphic traps in the Gulf of Guinea, West Africa and the discovery of the Jubilee Field: a play opening discovery in the Tano Basin, Offshore Ghana. Geological Society of London, Special Publication 369:235248.

Darros de Matos, R. M., 1999. History of the northeast Brazilian rift system: kinematic implicationsfor the break-up between Brazil and West Africa. In: Cameron, N.R., Bate, R.H. \& Clure, V.S. (eds): The oil and gas habitats of the South Atlantic. Geological Society of London, SpecialPublication 153: 55-73.
Dronkert, H. \& Wong, T.E., 1993. Geology of the Tambaredjo oil field, Suriname. AAPG Bulletin 77(2): 314.

Goss, S.J., Mosher, D.C., Wach, G.D. \& Kean, A.E., 2009. Cenozoic shelf to slope transition along a passive continental margin: Suriname, South America. Search and Discovery Article \#10222, www.searchanddiscovery. com/documents/2009/10222goss/ndx_goss.pdf

Griffith, C., 2015. Evaluation of the hydrocarbon potential of the ultra-deep offshore area of Suriname. MSc Thesis. Anton de Kom University (ADEKUS) (Paramaribo).

Henderson, T., 2014. Cretaceous fan plays of the African Transform Margin. Houston Geological Society Bulletin 57(1): 25.

Lamorde, U.A., 2012. A geochemical study of the origins of biodegraded oils and seeps from Nigeria, Ghana and Scotland. PhD Thesis. University of Aberdeen (Aberdeen): $198 \mathrm{pp}$.

Leo, C.T.A.M., Van de Weerd, A.A., Maaijwee, C.N.P.J., Boeker, U., Collin, S., Ramdajal, R. \& Paidin, R., 2015. Reservoir characterization and modelling of the Paleocene Tambaredjo Field, Suriname. 77th EAGE Conference and Exhibition 1-4 June 2015, Madrid. doi: 10.3997/2214-4609.201413082.

Mosher, D.C., Erbacher, J., Malone, M.J. \& Leg 207 Scientific Party. 2004. Demerara Rise: equatorial Cretaceous and Paleogene paleoceanographic transect, Western Australia. Covering Leg 207 of the cruises of the drilling vessel 'Joides Resolution', Bridgetown, Barbados, to Rio de Janeiro, Brazil, Sites 1257-1261, 11 January-6 March 2003. Proceedings of the Ocean Drilling Program, initial reports, vol. 207. Texas A \& M University 0cean Drilling Program (College Station, TX): 89pp.

Nemčok, M., Rybár, S., Ekkertová, P., Kotulová, J., Hermeston, S.A. \& Jones, D., 2015. Transform margin model of hydrocarbon migration: the GuyanaSuriname case study. Geological Society of London, Special Publication 431. doi: 10.1144/SP431.6.

Rivera Rabelo, I., 2006. 3D geological object recognition in high-resolution seismic data, a case study from a Palaeocene fluvio-estuarine reservoir in Suriname. PhD Thesis. Delft University of Technology (Delft): 110 pp., with appendices.

Schiefelbein, C., Zumberge, J., Cameron, N. \& Brown, S.W., 2000. Geochemical comparison of crude oil along the South Atlantic margins. In: Mello, M.R. \& Katz, B.J. (eds): Petroleum systems of South Atlantic margins. AAPG Memoir 73: 15-26.

Trabucho Alexandre, J., 2011. Mesozoic sedimentation in the North Atlantic and Western Tethys. Geologica Ultraiectina 335: 168 pp.

Wells, S., Warner, M., Greenhalgh, J. \& Borsato, R., 2012. Deepwater potential in Cote d'Ivoire. GeoExpro 9(3): 36-39.

Whaley, J., 2010. From Gold Coast to Black Gold. GeoExpro 7(3): 46-48.

Wong, Th.E., 1989. Revision of the stratigraphy of the coastal plain of Suriname. Natuurwetenschappelijke Studiekring voor Suriname en de Nederlandse Antillen 125: 1-64.

Wong, Th.E., 1998. Hydrocarbon exploration and exploitation in Suriname. In: Wong, Th.E. et al. (eds): The history of earth sciences in Suriname. Royal Netherlands Academy of Arts and Sciences, Netherlands Institute of Applied Geosciences TNO (Amsterdam): 377-393.

Wong, Th. E., 2014. Geological development of the coastal plain of Suriname. Memorias Geological Map of South America Workshop, 22-23 July 2014, Villa de Leyva, Colombia: 164-177. Conference proceedings.

Yang, W. \& Escalona, A., 2011. Tectonostratigraphic evolution of the Guyana Basin. AAPG Bulletin 95: 1339-1368. 